\title{
A SUBCHRONIC TOXICITY TEST OF ETHANOL EXTRACT FROM TUNJUK LANGIT RHIZOME (HELMINTHOSTACHYS ZEYLANICA) ON ALBINO RATS, RATTUS NOVERTICUS (WISTAR STRAIN)
}

\author{
FITRYA $^{1 *}$, NAJMA ANNURIA FITHRY ${ }^{1}$, MUHARNI ${ }^{2}$ \\ ${ }^{1}$ Department of Pharmacy, Faculty of Mathematics and Natural Sciences, University of Sriwijaya, Jl. Raya Palembang-Prabumulih Km 32, \\ Indralaya, Ogan Ilir, South Sumatra, Indonesia. ${ }^{2}$ Department of Chemistry, Faculty of Mathematics and Natural Sciences, University of \\ Sriwijaya, Jl. Raya Palembang-Prabumulih Km 32, Indralaya, Ogan Ilir, South Sumatra, Indonesia. Email: fitrya.ysp@gmail.com
}

Received: 06 October 2016, Revised and Accepted: 10 November 2016

ABSTRACT

Objective: Traditionally, Tunjuk langit (Helmynthostachis zaylanica) rhizome has been used as anticancer and anti-inflammation drugs; however, it may have toxic effects on major organs for a long-term continuously consecutive consumption. Therefore, this study was carried out to test subchronic toxicity of the ethanol extract of the rhizome on Albino rats, Rattus noverticus (Wistar strain).

Methods: A total of 100 male and female rats were divided into five groups. Groups I, II, III, and IV were orally administered with ethanol extracts of $68,136,272$, and $554 \mathrm{mg} / \mathrm{kg}$ body weight (BW), respectively. Meanwhile, Group V used as a control was no treatment with the extract. A toxic symptom has been observed by analyzing several parameters, namely BW, hematologic and biochemical properties, macroscopic organs, and relative organ weight.

Results: In general, the results show that there is no any toxic symptom and statistically insignificant differences in these parameters between treated and control groups.

Conclusion: We conclude that the ethanol extract of Tunjuk Langit rhizome does not have effects of subchronic toxicity.

Keywords: Tunjuk langit rhizome, Ethanol extract, Subchronic toxicity.

(c) 2017 The Authors. Published by Innovare Academic Sciences Pvt Ltd. This is an open access article under the CC BY license (http://creativecommons. org/licenses/by/4. 0/) DOI: http://dx.doi.org/10.22159/ajpcr.2017.v10i2.15563

\section{INTRODUCTION}

Previous studies on chemical contents of the Tunjuk Langit rhizome had found ugonstilbene A-C, eight flavonoids, and ugonin A-L [1-3]. The flavonoids have significant effects of anticancer [3], antioxidant [4,5], and anti-inflammation activities [6]. We also successfully identified a secondary metabolite from endophitic fungi Cohlibulus lunatus of Tunjuk langit rhizome [7]. Furthermore, the extract of this rhizome has aphrodisiac, neuroprotective, and antihyperuricemia activities [8-10]. The use of traditional medicine has been based on scientific authentication for chemical, pharmacology, toxicity herbs, and their standard quality to guarantee a direct impact on their safety and efficacy [11]. Our previous study showed that an ethanol extract of tunjuk langit rhizome could decrease in uric acid level in blood and this ethanol extract was standardized [12]. A median effective dose $\left(E D_{50}\right)$ of ethanol extract as antihyperuricemia is $135.67 \mathrm{~g} / \mathrm{kg}$ body weight (BW) and this extract fulfills the standard parameter $[10,12,13]$. The tunjuk langit rhizome has been traditionally used as anticancer and anti-inflammatory medicines. If the extract is used as a longterm continuously consecutive consumption, it may have toxic effects on vital organs. However, a detailed study on the toxic effects of this extract has not been conducted yet. Therefore, this research aims to test subchronic toxicity of the ethanol extract of tunjuk langit rhizome.

\section{METHODS}

The rhizomes of tunjuk langit plant were collected from the district of Sekayu, Musi Banyuasin Regency, South Sumatra, Indonesia. The plant can be found in other places in South Sumatera, such as Indralaya and Lahat, and they were used in our previous studies [3]. Other materials used in this study were $96 \%$ ethanol, microhematocrit, pentobarbital, and Albino rats, Rattus noverticus (wistar strain). The experiments were performed after accepting an approval letter of the protocol "Ethical
Clearance" from the Ethics Committee of Gadjah Mada University (No.166/KEC-LPPT/VI/2014) and were carried out in accordance with current guidelines for the care of laboratory animals.

The rhizome of tunjuk langit was powdered using a blender and the $96 \%$ ethanol was distillated using distillation apparatus. The extract of the rhizome was obtained from maceration of $3 \mathrm{~kg}$ the rhizome with $20 \mathrm{~L}$ distillated ethanol for 2 days. The maceration was then concentrated using a rotary evaporator. 100 albino rats as tested animals with BW of 180-200 g were divided into 5 groups, 10 male and 10 female rats per group. Four groups were treated with the extract of tunjuk langit rhizome and another one as a control. Group I-IV were treated with ethanol extract of $68 \mathrm{mg} / \mathrm{kg}$ BW; $136 \mathrm{mg} / \mathrm{kg} \mathrm{BW;} 272 \mathrm{mg} / \mathrm{kg} \mathrm{BW}$; and $554 \mathrm{mg} / \mathrm{kg}$ BW, respectively. Group V as a control was no treatment with the extract. The treatment by oral administration was once per day for 12 weeks. As long as the treatment, the tested rats were fed with normal food and drink constantly every day.

Toxic symptoms were observed by means of analyses of BW, hematologic and biochemical parameters, and macroscopic organs. This analysis was also done to test chronic of the extract of Pellionia heyneana Wedd. Leaf [14]. A dose $\left(\mathrm{ED}_{50}\right)$ used in this research is $135.67 \mathrm{~g} / \mathrm{kg} \mathrm{BW}$ [9]. The behavior and motoric activity of the tested animals were monitored every day and their BW was measured every week. On the $45^{\text {th }}$ and $91^{\text {st }}$ day blood of tested rats was taken from plexus retro orbitalis of their eyes by microhematocrit to measure blood parameters. The rats were also surgically cut using a scalpel knife and take out their vital organs, that is, liver, heart, and kidney, from their body using a pinset to do an organ inspection on the $91^{\text {st }}$ day. Before surgical cutting, euthanasia was applied to the rats with $15 \mathrm{mg} / 100 \mathrm{~g} \mathrm{BW}$ sodium pentobarbital through intra peritoneal. Parameters of hematologic and biochemical tests include levels of hemoglobin, leukocytes, erythrocyte, protein, 
urea, creatinine, serum glutamic oxaloacetic transaminase (SGOT), and serum glutamic-pyruvic transaminase (SGPT). Meanwhile, the analyses of macroscopic organs were performed by comparing color and appearance of the vital organs of treated rats with those of control rats. Furthermore, the relative organ weights (ROWs) were also calculated. The weight of the vital organ of the treated rats was then compared to that of the control group [14].

We used one-way analysis of variance followed by Dunnet's post-hoc to evaluate differences among groups. The significance level was set at $5 \%(\mathrm{p}<0.05)$.

\section{RESULTS AND DISCUSSION}

Subchonic toxicity is adverse effects occurring after the repeated or continuous administration of a test sample for a part of the animal's lifespan. First, we analyzed the motoric activity and BW of albino rats as signs of toxicity to observe treatment effects. $1 \mathrm{hr}$ after administrating the ethanol extract of tunjuk langit rhizomes showed no decrease in motoric activity and no death of treated rats. The treated rats could normally walk and climb after the administration. It indicates that the extract had no an effect on their motoric activity as shown in Table 1.

In addition, a BW is important to initially describe a health of human and animal because changes in the BW are a highly sensitive indicator [15]. During 12-week treatment, average BWs of both male and female rats increased 15-17 g/week as shown in Table 2. From statistical analysis, the significance value is 0.146 . It means that the extract administration had no adverse effects on BW.

Besides the motoric activity and BW, biochemical parameters were evaluated to observe liver and kidney functions. The damage in the liver can be used to indicate toxic substances. Two aminotransferase enzymes that are most commonly associated with liver cell damage are SGOT and SGPT. Measurement of the enzyme concentration in the blood by measuring the level of SGOT and SGPT can provide important information regarding the level of liver dysfunction. In general, one-way variance analysis showed that the levels of SGOT and SGPT of treated groups were insignificantly different from those of control group as shown in Table 3. However, the treated Group I (especially male rats) has significantly different level of SGOT from the control group. To clarify this result, some factors can be useful in differentiating a significant difference from control values, from

Table 1: The toxic symptom to tested rats after extract injection

\begin{tabular}{llll}
\hline Group & Treatment & $\begin{array}{l}\text { Number } \\
\text { of rats }\end{array}$ & $\begin{array}{l}\text { Motoric } \\
\text { activity }\end{array}$ \\
\hline I & Extract dose $68 \mathrm{mg} / \mathrm{kg} \mathrm{BW}$ & 20 & Normal \\
II & Extract dose $136 \mathrm{mg} / \mathrm{kg} \mathrm{BW}$ & 20 & Normal \\
III & Extract dose $272 \mathrm{mg} / \mathrm{kg} \mathrm{BW}$ & 20 & Normal \\
IV & Extract dose $554 \mathrm{mg} / \mathrm{kg} \mathrm{BW}$ & 20 & Normal \\
V & No extract treatment (control) & 20 & Normal \\
\hline
\end{tabular}

BW: Body weight

Table 2: BW increase of tested rats

\begin{tabular}{llll}
\hline Group & Gender & BW $(\mathbf{g})$ & Significance value (p) \\
\hline I & Male & $15.95 \pm 1.32$ & 0.967 \\
& Female & $16.50 \pm 0.72$ & 0.929 \\
II & Male & $17.21 \pm 1.27$ & 0.050 \\
& Female & $17.24 \pm 0.58$ & 0.330 \\
III & Male & $15.64 \pm 1.00$ & 0.684 \\
& Female & $15.48 \pm 0.82$ & 0.123 \\
IV & Male & $16.41 \pm 1.27$ & 0.482 \\
& Female & $16.55 \pm 1.17$ & 0.975 \\
V & Male & $15.93 \pm 1.37$ & - \\
& Female & $16.56 \pm 0.90$ & - \\
\hline
\end{tabular}

BW: Body weight a treatment-related effect [16]. This difference is less likely to be an effect of treatment if There is no obvious dose response; it is due to finding(s) in one or more animals that could be considered outlier(s) and/or it is within normal biological variation (within the range of reference value).

Analyses of creatinine and urea levels aim to investigate of kidney function. An increase in blood urea and creatinine level is an indication of kidney disfunction. Statistical analysis showed there is no significant difference in creatinine level between treated and control groups $(p=0.569)$. In general, urea concentrations are no significant difference between treated and control groups. According to some factors [16] and as in the SGOT level above, this difference is less likely to be an effect of treatment. Moreover, there were no differences in both the appearance and physical parameters of kidney between treated and control groups. Overall, the results of statistical analysis can be shown in Table 4 and it can be indicated that the extract had no an adverse effect in kidney function.

Parameters of rat's blood hematological test include hemoglobin, erythrocyte, leucocyte and total plasmatic protein as shown in Table 5. There were no significant differences in hematologic parameters between treated and control groups. From statistical analysis, significance values of hemoglobin, leukocyte, and total protein are 0.07 , 0.890 , and 0.219 , respectively, whereas erythrocyte is significantly different. This difference is clearly shown between male Group II $(\mathrm{p}=0.008)$ and female Group I $(\mathrm{p}=0.007)$; however, average level of erythrocyte is still normal, that is, $6.7-20 \times 10^{6} \mathrm{~mm}^{3}$ [17]. Moreover, the concentration of total plasmatic protein in male rats of Group I and II showed significantly different. These concentrations are lower than that in control group (i.e., 5.6-7.6 g/dl). While the concentration of total plasmatic protein in female rats of treated groups are insignificantly different from that of control group. Overall, the results of hematological test showed that the extract does not have side effects in a hematological system of treated rats.

Table 3: The SGPT and SGOT levels for male and female rats

\begin{tabular}{|c|c|c|c|c|c|}
\hline \multirow[t]{2}{*}{ Group } & \multirow[t]{2}{*}{ Gender } & \multicolumn{2}{|l|}{ SGPT level } & \multicolumn{2}{|l|}{ SGOT level } \\
\hline & & $(U / L)$ & $\mathbf{p}$ & $(U / L)$ & $\mathbf{p}$ \\
\hline \multirow[t]{2}{*}{ I } & Male & $17.00 \pm 1.09$ & 0.144 & $59.80 \pm 20.49$ & $0.037^{*}$ \\
\hline & Female & $17.20 \pm 1.60$ & 0.503 & $37.80 \pm 17.30$ & 0.611 \\
\hline \multirow[t]{2}{*}{ II } & Male & $16.80 \pm 1.46$ & 0.184 & $67.22 \pm 13.30$ & 0.171 \\
\hline & Female & $16.20 \pm 2.31$ & 1.000 & $31.40 \pm 16.44$ & 0.877 \\
\hline \multirow[t]{2}{*}{ III } & Male & $14.00 \pm 2.36$ & 0.591 & $75.00 \pm 15.29$ & 0.555 \\
\hline & Female & $13.08 \pm 2.03$ & 0.112 & $39.40 \pm 25.68$ & 0.502 \\
\hline \multirow[t]{2}{*}{ IV } & Male & $14.20 \pm 1.93$ & 0.687 & $73.60 \pm 6.83$ & 0.464 \\
\hline & Female & $18.80 \pm 2.07$ & 0.086 & $52.20 \pm 11.34$ & 0.053 \\
\hline \multirow[t]{2}{*}{ V } & Male & $14.80 \pm 2.70$ & - & $80.80 \pm 10.13$ & - \\
\hline & Female & $16.20 \pm 1.16$ & - & $32.80 \pm 3.37$ & - \\
\hline
\end{tabular}

*Significantly different from control group. SGPT: Serum glutamic-pyruvic

transaminase, SGOT: Serum glutamic oxaloacetic transaminase

Table 4: Average levels of urea and creatinine in tested rats

\begin{tabular}{|c|c|c|c|c|c|}
\hline \multirow[t]{2}{*}{ Group } & \multirow[t]{2}{*}{ Gender } & \multicolumn{2}{|l|}{ Urea level } & \multicolumn{2}{|c|}{ Creatinine level } \\
\hline & & (mg/dl) & $\mathbf{p}$ & (mg/dl) & $\mathbf{p}$ \\
\hline \multirow[t]{2}{*}{ I } & Male & $19.7 \pm 5.47$ & 0.972 & $1.06 \pm 0.42$ & 0.080 \\
\hline & Female & $18.7 \pm 2.01$ & 0.483 & $0.90 \pm 0.37$ & 1.000 \\
\hline \multirow[t]{2}{*}{ II } & Male & $15.5 \pm 2.17$ & 0.154 & $0.70 \pm 0.25$ & 0.916 \\
\hline & Female & $18.1 \pm 6.53$ & 0.363 & $1.00 \pm 0.55$ & 0.600 \\
\hline \multirow[t]{2}{*}{ III } & Male & $12.9 \pm 0.74$ & $0.023^{*}$ & $0.75 \pm 0.05$ & 0.875 \\
\hline & Female & $20.0 \pm 1.36$ & 0.648 & $0.82 \pm 0.39$ & 0.675 \\
\hline \multirow[t]{2}{*}{ IV } & Male & $20.0 \pm 4.74$ & 0.888 & $0.75 \pm 0.11$ & 0.875 \\
\hline & Female & $24.1 \pm 4.42$ & 0.236 & $0.93 \pm 0.10$ & 0.875 \\
\hline \multirow[t]{2}{*}{ V } & Male & $19.6 \pm 8.51$ & - & $0.72 \pm 0.08$ & - \\
\hline & Female & $20.7 \pm 0.97$ & - & $0.90 \pm 0.10$ & - \\
\hline
\end{tabular}

*Significantly different from control group 
Table 5: The results of hematologic evaluation

\begin{tabular}{|c|c|c|c|c|c|}
\hline \multirow[t]{2}{*}{ Parameter } & \multirow[t]{2}{*}{ Treatment } & \multicolumn{2}{|l|}{ Male } & \multicolumn{2}{|l|}{ Female } \\
\hline & & Average \pm SD & $\mathbf{p}$ & Average \pm SD & $\mathbf{p}$ \\
\hline \multirow[t]{4}{*}{ Hemoglobin (g/dL) } & Extract 68 mg/kg BW & $12.22 \pm 1.22$ & 0.755 & $10.90 \pm 0.61$ & 0.209 \\
\hline & Extract $272 \mathrm{mg} / \mathrm{kg}$ BW & $13.32 \pm 0.33$ & 0.763 & $13.10 \pm 2.08$ & 0.833 \\
\hline & Extract $554 \mathrm{mg} / \mathrm{kg} \mathrm{BW}$ & $14.06 \pm 0.58$ & 0.504 & $12.38 \pm 1.11$ & 0.463 \\
\hline & Control & $13.55 \pm 0.23$ & - & $12.94 \pm 1.66$ & - \\
\hline \multirow[t]{5}{*}{ Leukocyte $\left(\times 10^{3} / \mathrm{mm}^{3}\right)$} & Extract 68 mg/kg BW & $11.50 \pm 3.20$ & 0.568 & $11.60 \pm 1.27$ & 0.607 \\
\hline & Extract $136 \mathrm{mg} / \mathrm{kg} \mathrm{BW}$ & $12.46 \pm 1.60$ & 0.731 & $11.64 \pm 2.69$ & 0.634 \\
\hline & Extract $272 \mathrm{mg} / \mathrm{kg} \mathrm{BW}$ & $11.48 \pm 0.28$ & 0.555 & $12.40 \pm 1.82$ & 0.804 \\
\hline & Extract 554 mg/kg BW & $10.80 \pm 1.14$ & 0.219 & $11.84 \pm 1.26$ & 0.775 \\
\hline & Control & $12.10 \pm 0.50$ & - & $12.14 \pm 0.21$ & - \\
\hline \multirow[t]{5}{*}{ Erythrocyte $\left(\times 10^{6} / \mathrm{mm}^{3}\right)$} & Extract 68 mg/kg BW & $8.12 \pm 0.92$ & 0.062 & $7.20 \pm 0.25$ & $0.007^{*}$ \\
\hline & Extract 136 mg/kg BW & $7.72 \pm 0.62$ & $0.008^{*}$ & $8.46 \pm 0.96$ & 0.931 \\
\hline & Extract 272 mg/kg BW & $8.90 \pm 0.10$ & 0.829 & $8.12 \pm 1.00$ & 0.412 \\
\hline & Extract $554 \mathrm{mg} / \mathrm{kg} \mathrm{BW}$ & $9.30 \pm 0.38$ & 0.517 & $8.16 \pm 0.75$ & 0.463 \\
\hline & Control & $9.00 \pm 0.20$ & - & $8.50 \pm 1.11$ & - \\
\hline \multirow{4}{*}{ Total plasmatic protein $(\mathrm{g} / \mathrm{dL})$} & Extract 136 mg/kg BW & $4.84 \pm 0.75$ & $0.026^{*}$ & $7.66 \pm 0.58$ & 0.194 \\
\hline & Extract 272 mg/kg BW & $5.22 \pm 0.19$ & 0.093 & $7.44 \pm 1.49$ & 0.331 \\
\hline & Extract $554 \mathrm{mg} / \mathrm{kg} \mathrm{BW}$ & $5.52 \pm 0.14$ & 0.215 & $8.08 \pm 0.79$ & 0.056 \\
\hline & Control & $6.34 \pm 1.35$ & - & $6.80 \pm 1.21$ & - \\
\hline
\end{tabular}

*Significantly different from control group. BW: Body weight, SD: Standard deviation

Table 6: Relative organ weight of tested and control rats

\begin{tabular}{|c|c|c|c|c|c|c|c|}
\hline \multirow[t]{2}{*}{ Group } & \multirow[t]{2}{*}{ Gender } & \multicolumn{2}{|c|}{ ROW of liver } & \multicolumn{2}{|c|}{ ROW of heart } & \multicolumn{2}{|l|}{$\begin{array}{l}\text { RoW of } \\
\text { kidney }\end{array}$} \\
\hline & & $\times 10^{-2}$ & $\mathbf{p}$ & $\times 10^{-3}$ & $\mathbf{p}$ & $\times 10^{-3}$ & $\mathbf{p}$ \\
\hline \multirow[t]{2}{*}{ I } & Male & $2.65 \pm 1.0$ & 0.744 & $3.7 \pm 1.4$ & 0.995 & $5.9 \pm 1.8$ & 0.694 \\
\hline & Female & $3.25 \pm 0.0$ & 0.277 & $3.4 \pm 0.1$ & 0.938 & $7.0 \pm 0.9$ & 0.245 \\
\hline \multirow[t]{2}{*}{ II } & Male & $2.95 \pm 0.0$ & 1.000 & $3.5 \pm 0.3$ & 0.992 & $7.2 \pm 1.8$ & 0.997 \\
\hline & Female & $3.54 \pm 0.1$ & 0.902 & $4.2 \pm 1.5$ & 0.700 & $7.5 \pm 2.1$ & 0.755 \\
\hline \multirow[t]{2}{*}{ III } & Male & $3.85 \pm 1.3$ & 0.300 & $4.0 \pm 1.1$ & 0.985 & $8.1 \pm 1.8$ & 0.894 \\
\hline & Female & $3.92 \pm 0.0$ & 0.076 & $3.8 \pm 0.4$ & 0.645 & $8.8 \pm 1.7$ & 0.420 \\
\hline \multirow[t]{2}{*}{ IV } & Male & $2.93 \pm 3.8$ & 0.823 & $4.2 \pm 0.3$ & 0.974 & $7.7 \pm 0.6$ & 0.851 \\
\hline & Female & $3.06 \pm 0.0$ & 0.341 & $2.9 \pm 0.4$ & 0.938 & $5.8 \pm 1.1$ & 0.368 \\
\hline \multirow[t]{2}{*}{ V } & Male & $3.25 \pm 1.0$ & - & $4.2 \pm 0.7$ & - & $8.5 \pm 0.9$ & - \\
\hline & Female & $3.31 \pm 0.0$ & - & $3.0 \pm 0.7$ & - & $6.8 \pm 1.8$ & - \\
\hline
\end{tabular}

ROW: Relative organ weight

This study also carried out a macroscopic evaluation on vital organs (i.e., liver, heart, and kidney). This analysis aims to correlate toxic properties with changes in the organ structure of treated rats. From the macroscopic evaluation including color, appearance, and ROW showed that there were not significantly different and no specific anomalies on treated groups compared to control group. There were no lesion, inflammation or fattening on liver. Moreover, the color and physical appearance were normal. Statistical analysis showed no influence the extract administration to ROWs of liver $(p=0.88)$, heart $(p=0.952)$, and kidney $(p=0.332)$. It can be indicated that there were no significant differences between treated and control group as shown in Table 6 .

Overall, this study showed that there were insignificant differences in observed parameters between treated and control rats during extract administration. Thus, it can be said that this extract can be continuously consecutive consumed for long-term. In fact, the extract has properties as hepatoprotective [18] and neuroprotective [19]. Finally, the results of this study provide important information of the use of the tunjuk langit rhizome as traditional medicine, especially in South Sumatra, Indonesia.

\section{CONCLUSION}

In this study, we evaluate the subchronic toxicity of ethanol extract of tunjuk langit rhizome (Helminthostachys zeylanica) on albino rats, $R$. noverticus (Wistar strain), which the evaluation has used analyses on the BW, hematologic and biochemical parameters, and macroscopic organs. They indicated no death observed and no significant differences in motoric activity, BW, biochemical and hematologic parameters, and macroscopic organs between treated and control groups. The results showed that ethanol extracts of tunjuk langit rhizome in dose 68, 136, 272 and $554 \mathrm{mg} / \mathrm{kg} \mathrm{BW}$ had no significant toxicity.

\section{ACKNOWLEDGMENT}

We gratefully acknowledge the support Sriwijaya University, sponsored by "Penelitian Hibah Bersaing," Ministry of Research Technology and Higher Education, Indonesia. The authors would also like to thank Dr. Mokhamad Yusup Nur Khakim for his very helpful assistance and suggestions of this manuscript.

\section{REFERENCES}

1. Murakami T, Hagiwara M, Tanaka K, Chen CM. Chemicshe untersuchungen uber die inhaltsstoffe von Helminthostachys zeylanica (L). Chem Pharm Bull 1973;21:1851-2.

2. Chen CC, Huang YL, Yeh PY, Ou JC. Cyclized geranyl stilbenes from the rhizomes of Helminthostacys zeylanica. Planta Med 2003;69(10):964-7.

3. Fitrya, Anwar L, dan Eliza M. Ugonin J flavonoid from tunjuk langit (Helmynthostchys zeylanica) root extract. Indones $\mathrm{J}$ Chem Univ Gadjahmada 2010;10:226-31.

4. Muharniic F. Antioxidant Flavonoids from Tunjuk Langit (Helminthostachys zaylana), Proceeding of International Seminar Exploring Research Potentials, Palembang; 2011.

5. Huang YL, Yeh PY, Shen CC, Chen CC. Antioxidant flavonoids from the rhizomes of Helminthostachys zeylanica. Phytochemistry 2003;64(7):1277-83

6. Huang YC, Hwang TL, Chang CS, Yang YL, Shen CN, Liao WY, et al. Anti-inflamatory flavonoids from the rhizome of Helminthostachys zeylanica. Nat Prod 2009;72(7):1273-8.

7. Fitrya. Secondary metabolite from endophitic fungi cohlibulus lunatus of tunjuk langit (Helminthostachys zaylanica) rhizome. Indones $\mathrm{J}$ Chem 2013;13(3):193-8.

8. Suja SR, Latha PG, Pushpangadan P, Raasekharan S. Aphrodisiac property of Helminthostachys zaylanica in male mice. J Trop Med Plants 2002;3:191-5.

9. Suja SR, Latha PG, Pushpangadan P, Rajasekharan S. Evaluation of hepatoprotective effects of Helminthostachys zeylanica (L.) Hook against carbon tetrachloride-induced liver damage in Wistar rats. J Ethnopharmacol 2004;92(1):61-6

10. Fitrya, Muharni. An antihyperuricemia effect of ethanol extract of tunjuk langit rhizome (Helminthostachys zaylanica Linn Hook) on 
Swiss furrow male mice. Traditional Med J 2014;19(1):4-18. Available from: https://www.jurnal.ugm.ac.id/TradMedJ/article/view/8085.

11. Departement Kesehatan RI. Pedoman pelaksanaan uji klinik obat tradisional. Direktorat Jenderal Pengawasan Obat dan Makanan. Direktorat Pengawasan Obat Tradisional. Jakarta: Departement Kesehatan RI; 2002.

12. Fitrya, Muharni. Standardisasi Ekstrak Aktif Akar Tunjuk Langit, Seminar Nasional Biodiversitas. Solo, Indonesia: Universitas Negeri Surakarta; 2013

13. Ditjen POM Depkes RI. Parameter Standar Umum Ekstrak Tumbuhan Obat, Direktorat Jenderal Pengawasan Obat dan Makanan, Direktorat Pengawasan Obat Tradisional. Jakarta: Departemen Kesehatan; 2000.

14. Vilash V, Suja SR, Latha PG, Shine VJ, Sekharan SR. Chronic oral toxicity studies of ethanolic extract and ethanolic fraction extract of Pellionia Heyneana wedd. Leaf in Wistar rats. Int J Pharm Pharm Sci 2016;8(8):306-12.
15. El Hilaly J, Israili ZH, Lyoussi B. Acute and chronic toxicological studies of Ajuga iva in experimental animals. J Ethnopharmacol 2004;91(1):43-50

16. Lewis RW, Billington R, Debryune E, Gamer A, Lang B, Carpanini F. Recognition of adverse and nonadverse effects in toxicity studies. Toxicol Pathol 2002;30(1):66-74

17. Mitruka BM, Rawnsley HM. Clinical Biochemical and Hematological Reference Values in Normal Experimental Animals and Normal Humans. $2^{\text {nd }}$ ed. New York: Masson; 1981.

18. Suja SR, Latha PG, Pushpangadan P, Shine VJ, Anuja GI, Bijukumar BS. Evaluation of antihepatotoxic potential of Helminthostachys zeylanica (Linn.) Hook. f., A medicinal fern against ethanol induced liver damage: In vitro and in vivo studies. Am J Exp Biol 2014;1(1):16-30.

19. Lin YC, Huang YC, Chen SC, Liaw CC, Kuo SC, Huang LJ, et al. Neuroprotective effects of ugonin $\mathrm{K}$ on hydrogen peroxide-induced cell death in human neuroblastoma SH-SY5Y cells. Neurochem Res 2009;34(5):923-30. 